\title{
JAPAN-INDIA RELATIONS IN THE LIGHT OF INDIA'S LOOK-EAST POLICY: STRENGTHENING THE KIZUNA
}

\begin{abstract}
Rupakjyoti Borah
Japan and India have long historical ties, which date back to the times when the monk, Bodhisena went to Japan and Buddhism spread in that country from the land of its birth, India, However, the two countries veered off during the period of the Cold War as they were on the opposite sides of the divide - Japan being an ally of the United States while India was close to the erstwhile Soviet Union. That, however, did not prevent India from supplying iron ore to Japan in the period after the end of the Second World War, which greatly helped Japan's reconstruction efforts. The relations between India and Japan have improved remarkably fast after the end of the Cold War so much so that the two countries are now "Special Strategic and Global Partners". Unlike most countries in Asia, Japan and India have no historical differences. Japan is the only country (apart from Russia) with which India has an annual bilateral summit. The paper will attempt to analyse the main areas of convergence and divergence between Japan and India. It examines the extent to which things have changed in the relationship following the launch of the "Look-East Policy" in the early 1990's. Last, but not the least, it attempts to lay down a roadmap for the future of Indo-Japanese ties.
\end{abstract}

Keywords: Japan, India, Look East Policy, Act East, Bilateral and Trilateral Cooperation

\section{Historical Background}

The relations between Japan and India date back to the distant past when Buddhism spread to Japan from the land of its birth, India. India's earliest ties with Japan date back to $752 \mathrm{AD}$ when an Indian monk Bodhisena performed the eye-opening ceremony of Lord Buddha's statue in Nara, Japan. The Japan-India Association (founded in 1903) stands testimony to the time-tested ties between the two nations and is the oldest international friendship association in that country ${ }^{2}$

The famous Indian poet Rabindranath Tagore was friends with Japanese scholars like Okakura Tenshin. During the colonial-era, Japan had helped Indian freedom fighter Subhash Chandra Bose set up the Indian National Army (INA) to fight the British, though it finally lost to the British forces in the Battle of Kohima, in Northeast India. Japan was also home to many other Indian revolutionaries like Rash Behari Bose while Indian judge Radha Binod Pal was the only dissenting voice at the Tokyo War Crimes Tribunal set up after the end of the Second World War and even today has a monument to his name enshrined in the Yasukuni shrine in Tokyo. Indian merchants began to settle down in cities like Yokohama and enjoyed brisk businesses.

\footnotetext{
Japanese word meaning bond.

2 India - Japan Relations, Embassy of India, Tokyo, Japan available at http://www. indembassy-tokyo.gov.in/bilateral_brief.html, accessed on 14 April, 2015.
} 
In the post-Second World War era, the first Indian Prime Minister Jawaharlal Nehru sent an elephant as a gift from India in 1949 to the Ueno Zoo in Tokyo which lifted people's spirits, after the devastation of the Second World War. India refused to attend the San Francisco Conference and signed a separate peace treaty with Japan and it also refused to accept any reparations from Japan. However, the two nations became rather estranged in the Cold War era as Japan became an ally of the United States while India became one of the founding members of the Non-Aligned Movement (NAM), though later India moved closer to the erstwhile Soviet Union, especially after the signing of the Indo-Soviet Treaty of Friendship and Cooperation in 1971. Nobusuke Kishi (the grandfather of present Japanese Prime Minister Shinzo Abe) became the first Japanese Prime Minister to visit India and New Delhi was the first recipient of yen loans given out by Tokyo in 1958. However, the insular economic policy followed by India after independence drove the two nations further apart. After Japanese Prime Minister Hayato Ikeda visited India in 1961, the next Japanese Prime Minister to visit India was Yasuhiro Nakasone in 1984. From the Indian side, PM Rajiv Gandhi visited Japan in 1988, after a long interval of 30 years. Meanwhile, the entry of the Japanese automaker, Suzuki, into the Indian market, in the early 1980's, revolutionalised the auto market in India travels and from then on, many Japanese automobile companies have entered the Indian market.

\section{Post-Cold War Era}

It was only after the end of the Cold War and the breakup of the erstwhile Soviet Union that Japan and India started coming closer to each other. Part of the reason was economic as India faced a balance of payments crisis and was forced to liberalise its economy. It also had to change its foreign policy orientation as its former benefactor, the Soviet Union was no longer there while its successor state, Russia, was mired in too many problems of its own.

Bilateral relations improved significantly in the light of India's "Look-East Policy" which aimed to rekindle India's ancient links with the countries of Southeast Asia and East Asia. In the past, Indian influence had spread throughout Southeast Asia and East Asia. Even today the state philosophy of Indonesia, Pancasila is derived from the Sanskrit words, Panca (meaning five) and sila (meaning principles). The world's most populous Islamic country, Indonesia, has the island of Bali which still retains a Hindu majority. Angkor Wat in Cambodia was a former Hindu temple, before it became a Buddhist temple. Buddhism also travelled to the countries of China, Japan and Korea from the land of its birth, India.

However, India's efforts to strengthen relations with Japan struck a roadblock in the wake of India conducting a set of nuclear explosions in May 1998. Japan protested vociferously and imposed a string of sanctions on India. The turnaround in the relations came with the visit of the then Japanese Prime Minister Yoshiro Mori to India in the year 2000 which led to the "Japan-India Global Partnership in the $21^{\text {st }}$ century". ${ }^{3}$ This was soon after the landmark visit of the US President, Bill Clinton, to India, earlier that year.

3 India - Japan Relations, Ministry of External Affairs, Government of India, available at http:/ / www.mea.gov.in/Portal/ForeignRelation/Japan_December_2014.pdf accessed on 13 April, 2015. 
It was in 2006 during the meeting between Indian Prime Minister Dr Manmohan Singh and Japanese PM Shinzo Abe that the relationship was upgraded to a Global and Strategic Partnership with an annual summit at the Prime Ministerial level. During Shinzo Abe's earlier stint as the PM he delivered a landmark speech in the Indian Parliament in August 2007 titled "Confluence of the Two Seas" ${ }^{4}$ where he mentioned that "by Japan and India coming together in this way, this "broader Asia" will evolve into an immense network spanning the entirety of the Pacific Ocean, incorporating the United States of America and Australia" ${ }^{5}$.

In the year 2008, Japan and India signed a momentous security treaty. Things have looked up after the election of Shinzo Abe as the Prime Minister of Japan in December 2012. It was in late November and early December 2013 that the Japanese Emperor and Empress visited India. This was very significant since it is very rare for the Japanese Emperor and Empress to travel outside India and that too to a country which is not a monarchy.

The Japanese PM Shinzo Abe was the Chief Guest at India's Republic Day celebrations in January 2014. The Republic Day parade is meant to showcase India's military prowess and the significance of the occasion would not be lost on countries like China. During his visit to India for the Republic Day celebrations in January 2014, PM Abe mentioned that "the relations between Japan and India have the greatest potential of any bilateral relationship anywhere in the world". ${ }^{6}$

Japan was the first country (outside the immediate neighbourhood) that PM Modi visited after taking over as the Prime Minister in May last year. During this visit, PM Modi visited Kyoto and Tokyo while Japanese PM Shinzo Abe broke protocol to receive Modi in Kyoto. During this visit, the two sides agreed to upgrade their relationship to a "Special Strategic and Global Partnership". During this visit, Japan also announced its intention to invest around $\$ 35$ billion in India over the course of the next 5 years in order to improve India's infrastructure sector.

In a first, India has also invited Japan to invest in India's Northeastern region to improve infrastructure in this remote and underdeveloped part of India and also to link it up through Myanmar as a part of India's "Look-East Policy". This is very important as in the past, India has been wary of letting foreigners into this part of the country because of the strategic location of Northeast India. The Tokyo Declaration for India - Japan Special Strategic and Global Partnership signed during the visit of PM Modi to Japan notes that "the two Prime Ministers placed special emphasis on Japan's cooperation for enhanced connectivity and development in Northeast India and linking

4 "Confluence of the Two Seas", Speech by Shinzo Abe, Prime Minister of Japan at the Parliament of the Republic of India, available at http:/ / www.mofa.go.jp/region/asia-paci/pmv0708/ speech-2.html, accessed on 13 April, 2015.

5 Ibid.

6 Ministry of External Affairs, Government of India, Media Statements of Prime Minister Dr. Manmohan Singh and Prime Minister of Japan Shinzo Abe at the press event held after the annual India-Japan summit level meeting, available at http:/ / mea.gov.in/media-briefings. htm?dtl/22782/Media+Statements+of+Prime+Minister+Dr+Manmohan+Singh+and+Prim e+Minister+of+Japan+Shinzo+Abe+at+the+press+event+held+after+the+annual+IndiaJapa n+summit+level+meeting, accessed on 2 April, 2015. 
the region to other economic corridors in India and to Southeast Asia, which would catalyse economic development and increase prosperity in the region."7

\section{Factors Bringing Japan and India Closer}

There are many factors which are bringing Japan and India closer. First, shared strategic and economic interests are bringing Tokyo and New Delhi closer. Japan's economy has been mired in recession and Tokyo's political equation with China has translated into rough times in the economic realm as well. Hence, Tokyo is looking for alternative options and New Delhi fits the bill perfectly because of its huge population and growing economy. On the strategic realm, India and Tokyo have no conflict of strategic interests which is rare for two countries in today's geopolitical environment. Japan has been closely involved in India's infrastructure sector - in projects like the Delhi Metro, the Delhi-Mumbai Industrial Corridor (DMIC) and Chennai-Bangalore Industrial Corridor (CBIC). In addition, the biggest chunk of Japan's ODA (Official Development Assistance) has come to India since the year 2003-04 and it is noteworthy that it has not shrunk even during the Fukushima disaster in Japan in the year 2011. Japan's help has been critical in constructing the Delhi Metro, relieving congestion in India's crowded capital city. Japan and India are also collaborating in the production of rare-earths. After the dispute over the Senkakus (which China claims as Diaoyu) flared up, China had stopped exporting rare-earths to Japanese companies and hence Japanese companies are looking for alternate sources all over the world.

Secondly, both India and Japan share concerns regarding China's intentions in the Asia-Pacific region. Both of them have territorial issues with China and in the recent past, China has been very aggressive and has been involved in disputes with many countries like the Philippines, Vietnam, Japan besides India. On many occasions, Chinese soldiers have transgressed into the Indian side of the border, including when the Chinese President was visiting India in September last year. On the other hand, Japan and China have been locking horns over the Japanese-held Senkaku islands (which are claimed as Diayou by China). Japanese businesses have suffered in China owing to these tensions with China.

Thirdly, India's growing ties with the United States in the post-Cold War era have also bought it closer to countries like Japan, which is an ally of the United States. The turnaround in the ties between the world's oldest democracy (USA) and the world's most populous democracy (India) started after the visit of the then US President Bill Clinton to India in the year 2000. Since then, the relations have moved at a very fast pace, especially after the signing of the US-India civilian nuclear deal.

There are many sections in Japan which understand that American power and influence in the Asia-Pacific is on the decline (though it still remains the pre-eminent power) and hence they favour closer ties with countries like India. Though relations between India and the US had floundered towards the end of the Manmohan Singhgovernment, Indian PM Modi paid a visit to the US in September last year, which helped to arrest the slide in the relations. The relations had been hit by differences over India's nuclear liability bill, the treatment of an Indian female diplomat in the US

\footnotetext{
7 "Tokyo Declaration for India - Japan Special Strategic and Global Partnership", available at http:/ / www.mea.gov.in/ outoging-visit-detail.htm?23965/Tokyo+Declaration+for+India+ +Japan+Special+Strategic+and+Global+Partnership, accessed on 9 April, 2015.
} 
and Washington losing interest in India as a result of the slowing down of the Indian economy.

The US President Barack Obama was the Chief Guest at India's Republic Day celebrations in January this year and he became the only US President to visit India twice during his Presidency. In a first, the US-India Joint Strategic Vision for the AsiaPacific and Indian Ocean Region issued during the US President Barack Obama's visit to India mentions that "we affirm the importance of safeguarding maritime security and ensuring freedom of navigation and over flight throughout the region, especially in the South China Sea," ${ }^{8}$ thus signalling that New Delhi is now beginning to openly express its misgivings vis-à-vis Beijing's unilateral actions in the South China Sea.

In the meantime, India's relations with countries with whom Japan has close ties, like Australia, also seem to be improving. In fact, Australian PM Tony Abbott was the first State Guest of the Modi administration. Australia has also gone ahead and signed a civilian nuclear deal with India. Canberra has the world's largest uranium deposits $^{9}$ which is critical for the success of India's nuclear energy programme. In the past, Australia had also refused to sign a civilian nuclear deal with India unless India acceded to the Nuclear Non-Proliferation Treaty (NPT), but things have changed now.

There have also been many others areas of cooperation between countries like India, Japan, Australia and the United States. These four countries started the "Quadrilateral Initiative" in 2007 though it suffered a swift death because of concerns from China. These four countries had also pooled their efforts in the wake of devastating Indian Ocean tsunami of December 2004.

Fourthly, the personal equation between leaders is also very important when it comes to the relations between nations. The Indian PM Narendra Modi and the Japanese PM Shinzo Abe seem to have struck a friendship between them so much so that PM Abe received PM Modi in Kyoto during his visit last year, rather than in Tokyo. PM Modi had visited Japan earlier as the Chief Minister of Gujarat, at a time, when he had been ostracised by most Western countries over the Gujarat riots of 2002. He had also succeeded in getting Japanese companies to invest in his home province of Gujarat.

Fifthly, there is cross-party support for close ties with Japan cutting across the political spectrum. Though the relations first started improving after the initiation of the "Look-East Policy" under the Congress government, it was carried on under the BJP-led NDA government. In fact, it was BJP's Atal Behari Vajpayee who was the Prime Minister during the visit of the former PM Yoshiro Mori of Japan, when the relations made a comeback after the chill in the relations in the wake of India's nuclear tests of 1998. Similarly, in Japan too, even with the frequent change of Prime Ministers, the bilateral relationship has not suffered.

Sixthly, Japan and India are collaborating in a host of international forums like the G-20, East Asia Summit and other organisations. Japan and India, along with Germany and Brazil, have teamed up to form the G-4 to press their case for permanent membership of the United Nations Security Council (UNSC). Japan was one of the key countries which backed India's entry into the East Asia Summit (EAS).

8 "US-India Joint Strategic Vision for the Asia-Pacific and Indian Ocean Region", available at http:// www.mea.gov.in/incoming-visit-detail.htm?24728/USIndia+Joint+Strategic+Visio $\mathrm{n}+$ for+the+AsiaPacific+and+Indian+Ocean+Region, accessed on 8 April, 2015.

9 "Australia's Uranium", available at http:/ / www.world-nuclear.org/info/Country-Profiles/ Countries-A-F/Australia/, accessed on 13 April, 2015. 


\section{The Security Situation in the Asia Pacific Region}

As China grows more powerful in the Asia-Pacific region, it has been accompanied by the concomitant decline in the power and influence of the United States in this part of the world. While the US, through its rebalance to the Asia-Pacific has tried to show that it still is in the game in the Asia-Pacific, the fact remains that it is China which is growing up to become the biggest challenger to the power and influence of the US in this part of the world. Backed by a buoyant economy and without having to fight wars in various parts of the world, China has been reaping the benefits of a peace dividend. It is in the background of this growing power of China, that a new synergy is taking place between India and Japan.

For Japan, India's importance lies in the fact that the Indian Navy is the most powerful actor in the Indian Ocean region, with the sole exception of the US. Japan is an oil-importing nation and imports a huge quantity of petroleum products from the Middle-East region. It is very important for Japan's energy security that the sea-lanes of communication are kept safe and open. In addition, the tri-services command in India's Andaman and Nicobar chain of islands is critically important for ensuring the safety of the sea lanes of communication in the Malacca Straits. The farthest point of India's Andaman and Nicobar chain of islands is only around 90 nautical miles from Indonesia's Aceh province, thus showing its huge strategic importance not only for India, but also for Japan.

China has also laid claims to the Japanese-held Senkaku islands (claimed as Diaoyu by China) and has also announced a new Air Defence Identification Zone(ADIZ) which overlaps with the ADIZ of Japan and South Korea. While the US soon after the announcement of a new ADIZ flew a military aircraft over the same in a rebuff to Beijing, the Japanese government has also asked Japanese airlines not to obey the same. Tensions between China and Japan have also increased after the election of Shinzo Abe as the PM of Japan. Abe, after his election, visited the controversial Yasukuni Shrine in Tokyo, angering Beijing and Seoul. It seems that both sides, Japan and China are in no mood to relent and have pursued a very recalcitrant stance.

With India too, China's actions have been similar. Time and again, there have been transgressions into the Indian side by Chinese soldiers who have crossed over even during the visit of the Chinese President, Xi Jinping to India in September last year. Indeed, it is highly unlikely (given the chain of command in China) that President Xi Jinping would not have known about the transgressions. China has also been progressing with Xi Jinping's pet initiative of the "Maritime Silk Road" which aims to create a maritime version of the so-called Silk Road which connected China to different parts of the world.

China claims the Indian province of Arunachal Pradesh and parts of the northern Indian province of Jammu and Kashmir and has been issuing stapled visas to the residents of these provinces, which has not gone down well with India. In addition, Beijing has repeatedly objected to the activities of the Dalai Lama in India, even though the Dalai Lama has not been allowed to indulge in any political activities in India.

Meanwhile, India has started raising a 45000-50000 strong mountain strike corps to be deployed along the border with China. Beijing is also raising its profile in the Indian Ocean region as it has now deployed its first aircraft carrier, the Liaoning. China has also been increasingly courting the countries in the Indian Ocean region like Sri 
Lanka, Mauritius, Maldives and Seychelles. These moves have not gone unnoticed in New Delhi and as a result India is warily reacting to the Chinese moves in the region.

China has also built up a string of ports in the Indian Ocean region in what many observers in India have termed as the "string of pearls" strategy where Beijing has helped to build ports in Gwadar (Pakistan), Hambantota (Sri Lanka), Kyaukpyu (Myanmar) and Chittagong (Bangladesh). The worry for India is that these ports could be used for military purposes as well in the event of the outbreak of any hostilities. China is also building a pipeline from Kyaukpyu to southern China, which will allow China to bypass the Straits of Malacca, which has been for long been termed as China's Achilles Heel.

Meanwhile, India's has also been ratcheting up its ties with countries like Vietnam since the launch of India's "Look-East Policy". In the past, China had asked India to withdraw its state-owned oil company, the ONGC (Oil and Natural Gas Corporation) from exploration activities close to the coast of Vietnam which it termed as "China's territorial waters". However, India has refused to comply with the Chinese demand.

Japan, after Shinzo Abe became Prime Minister in December 2012 has been trying to become a normal nation once again. Unlike many countries which see this as a threat, India has no such issues and in fact, welcomes Japan's rise. In July last year, Article 9 of the Japanese Constitution was also reinterpreted allowing Japan to come to the aid of its allies, thus showing that Japan is trying to move towards normalising itself.

\section{Major Areas of Cooperation}

\section{Trade}

As the Indian economy grows, every year it is adding millions of people into the middle class and it is this middle class that Japanese companies could be courting. Japan and India are also collaborating in creating smart cities. As India moves towards becoming the most populous country in the world, it will need innovative solutions in order to tackle serious issues like environmental pollution and sustainability.

Although, a Comprehensive Economic Partnership Agreement (CEPA) was concluded between Japan and India in 2011, the total amount of trade between India and Japan needs to be increased as it is still very miniscule as compared to India-China trade. China-India trade stood at US $\$ 70.65$ billion in $2014^{10}$ while trade between Japan and India stood at a measly $\$ 16.31$ billion during the fiscal year 2013-2014. Hence, there is a great potential to increase Japan-India trade as well.

A feasibility study is going on for a high-speed train service between Ahmedabad and India's commercial capital of Mumbai. For the economic revival of Japan, India could play a very critical role. One of India's key areas of expertise, I-T, has great potential to further deepen the ties with India. After PM Modi came to power, he has launched the "Make in India" initiative designed to attract foreign investment into India.

10 India-China relations, http://www.mea.gov.in/Portal/ForeignRelation/China_Jan_2015. pdf, accessed on 30 March, 2015. 
Table 1: India-Japan bilateral trade (In US\$ Billion)

\begin{tabular}{|l|r|r|r|r|r|r|r|}
\hline Year & $\mathbf{2 0 0 5 - 0 6}$ & $\mathbf{2 0 0 6 - 0 7}$ & $\mathbf{2 0 0 7 - 0 8}$ & $\mathbf{2 0 0 8 - 0 9}$ & $\mathbf{2 0 0 9 - 1 0}$ & $\mathbf{2 0 1 0 - 1 1}$ & $\mathbf{2 0 1 1 - 1 2}$ \\
\hline EXPORT & 2.48 & 2.87 & 3.86 & 3.02 & 3.63 & 5.09 & 6.33 \\
\hline India's Total Export & 103.09 & 126.41 & 163.13 & 185.29 & 178.75 & 251.13 & 305.96 \\
\hline \%Share & 2.41 & 2.27 & 2.37 & 1.63 & 2.03 & 2.07 & 2.07 \\
\hline IMPORT & 4.06 & 4.59 & 6.32 & 7.89 & 6.73 & 8.63 & 12.10 \\
\hline India's Total Import & 149.17 & 185.73 & 251.65 & 303.69 & 288.37 & 369.77 & 489.32 \\
\hline \%Share & 2.73 & 2.48 & 2.52 & 2.6 & 2.34 & 2.33 & 2.47 \\
\hline $\begin{array}{l}\text { TOTAL TRADE (with } \\
\text { Japan) }\end{array}$ & $\mathbf{6 . 5 4}$ & $\mathbf{7 . 4 6}$ & $\mathbf{1 0 . 1 8}$ & $\mathbf{1 0 . 9 1}$ & $\mathbf{1 0 . 3 6}$ & $\mathbf{1 3 . 7 2}$ & $\mathbf{1 8 . 4 3}$ \\
\hline
\end{tabular}

Source: India-Japan Economic Relations available at http://www.indembassy tokyo.gov.in/india_japan_ economic_relations.html.

\section{Defence}

Defence cooperation is likely to emerge as a major area of cooperation between India and Japan. India has already conveyed its interest in the Japanese-made US-2 maritime reconnaissance aircraft and talks are now underway for the same deal. If the deal goes through, it will represent a first for Japan. India is one of the world's largest importers of arms and Japanese companies could benefit tremendously from orders from the Indian market. India is also working at a massive indigenization of its defence sector and Japanese help could be very critical for India in this venture.

\section{Cooperation of Third Countries}

Another area of cooperation between Japan and India could be in third countries like Myanmar. Japan and India both have historical ties with Myanmar and after democracy has been "reintroduced" in Myanmar, both the countries could help Naypyidaw in various ways. Japan is also planning to help India in improving the infrastructure in the Northeastern region of India, which connects India to Myanmar. Indeed, for the success of India's "Look-East Policy", improving the infrastructure in India's Northeast region is critically important. The India-Myanmar-Thailand trilateral highway is already under construction, which when completed will connect with Da Nang in Vietnam. There could also be trilateral cooperation between countries like India, Japan and Vietnam. Japan and India also have the potential to cooperate in continents like Africa, especially given India's historical ties with many countries in the region owing to the presence of Indian Diasporas and common British colonial legacies.

There is also potential for Japan and India to cooperate in countries like Afghanistan. Both India and Japan are leading donors in Afghanistan and share an interest in maintaining peace and stability in that country especially now that the majority of the western forces have pulled out from that country.

\section{Trilateral Cooperation between India, Japan and the US}

India, Japan and the US have a trilateral dialogue between themselves which started in December 2011 with various rounds of talks being held in Washington DC, New Delhi and Tokyo. New Delhi and Tokyo also have a maritime dialogue between them 
in addition to joint naval exercises (JIMEX) between the two sides which started in 2012. Besides, the Coast Guards of India and Japan have already been holding joint exercises.

Japan has also participated in the Malabar naval exercises which are actually intended as bilateral exercises between India and the United States. In addition, now with India buying military hardware from the US, there are more prospects for cooperation and interoperability between the armed forces of United States, Japan and India.

\section{People to People Ties}

People-to-people ties are also very important. Japan should further relax its norms for entry of Indians, especially for short-term visits. The Indian movie industry, Bollywood, has been scouting for locales and has been filming in countries across the world. Japan could be a big draw for Japanese movies as well. There could also be increased collaboration between Indian and Japanese universities. The teaching of Japanese in India and of Indian languages in Japan needs to be encouraged. In addition, India needs to promote tourism by Japanese tourists, especially to Buddhist sites. India has already introduced a visa-on-arrival scheme for Japanese tourists. The Indian Diaspora in Japan should also be made a party to the improving ties between the two countries as has happened in the case of countries like the US, where the Indian Diaspora has played a leading role in pushing forward the ties to a higher trajectory.

\section{Main Areas of Disagreement}

A civilian nuclear deal has been elusive between the two sides although India has signed civilian nuclear deals with countries like the US, Russia, France, Australia among others. This is due to Japan's insistence that India should sign the Nuclear Non-Proliferation Treaty (NPT) which India has always considered as highly discriminatory. However, there is a huge domestic pressure in Japan as well to any prospective nuclear deal with a non-NPT country like India, given that Japan is the only country in the world to have suffered from the horrific impact of atomic bombing. The opposition has worsened in the aftermath of the meltdown in the Fukushima nuclear plant in March 2011 after the Great East Japan Earthquake.

India is looking at a massive increase in its nuclear power generation capacity and hence it is trying to secure nuclear cooperation, especially with countries possessing advanced nuclear technology like Japan. Japanese companies like Hitachi and Toshiba are major stakeholders in companies like GE and Westinghouse and hence without Japan's coming on board, fully operationalising the various nuclear deals India has signed with other countries like the US, Australia etc. would not be feasible

There is also a differing perception between India and Japan on how close they would like to get to the US. While Japan is a treaty ally of the US, in India the situation is quite different. Although India has moved close to the US in the period after the end of the Cold War, it still maintains close relations with countries like Russia while the US maintains close ties with Pakistan. The vision document Non-Alignment 2.0(prepared by some of India's leading strategists) mentions that "the historical record of the United States bears out that powers that form formal alliances with it have tended to see an erosion of their strategic autonomy. Both India and the U.S. may be better served by 
being friends rather than allies." ${ }^{11}$ India has also been unwilling to be a part of US initiatives like the Proliferation Security Initiative while it has reluctantly agreed to cut oil imports from countries like Iran in the face of American pressure.

There have also been concerns regarding the slow pace of implementation of some key projects in India and over the high-level of red tape when it comes to getting clearance from various departments for Japanese projects in India. During the visit of PM Modi to Japan last year, he had promised to set up a special team under the Prime Minister's Office (PMO) to speed up the clearance of Japanese projects in India. Some Japanese companies like Suzuki and Honda have also faced labour unrest in their plants in India owing to the differing working and managerial attitudes between India and Japan

India's close ties with Russia have sometime been a negative factor in the ties, especially as Japan has unresolved territorial disputes with Russia. Although, Japanese PM Shinzo Abe tried to improve Japan's relations with Russia, events in Ukraine, especially the annexation of Crimea by Russia have pushed the relations back to square one, especially after Russia was pushed out from the G8. Russia is also one of the major suppliers of defence weaponry to India, though in the recent past, India has been buying weapons from a host of other countries like the United States, France and Israel among others. India has also taken an ambivalent position on the issue of Crimea and Russian aid to separatists in Ukraine, something which has not gone down well in Tokyo.

\section{Conclusion}

It would not be unfair to say that Japan-India relations have progressed far more in the period after the end of the Cold War than in period between India's independence in 1947 till the end of the Cold War. While this is a very welcome augury, there are many loose ends which need to be tied in the relations between India and Japan.

To begin with, a civilian nuclear deal needs to be signed at the earliest between them since India's nuclear credentials have been affirmed by a host of countries across the world, including the United States. Even though India has not signed the NPT (the Nuclear Non-Proliferation Treaty) and CTBT (the Comprehensive Test Ban Treaty), it has never indulged in any kind of proliferation anywhere in the world and has also placed a voluntary moratorium on further testing. Japanese companies could then invest in India's nuclear sector which would be a win-win situation for both countries.

In addition, India should strike a deal for the purchase of the Shin Maywa US-2 aircraft from Japan as this will signal the dawn of a new era in the relations between the two countries. While it will be a first for Japan as far as defence sales are concerned, it will also be a big leap forward for India as far as defence procurement is concerned.

As Japan grapples with falling population levels, what is worth noting is that India is one of the youngest countries in the world and in the future, could act as one of the key supplier of highly-skilled labour in areas like nursing, medical services, engineers etc. In addition, Japanese companies can make use of India's strengths in areas like IT (Information Technology). India, especially, the southern provinces of the country (given

11 "Nonalignment 2.0- A Foreign and Strategic Policy for India in The Twenty First Century", available at http://www.cprindia.org/sites/default/files/NonAlignment\%202.0_1.pdf, accessed on 8 April, 2015. 
its access to the sea), could also become a manufacturing hub for Japanese companies to export to other parts of the world

The maritime realm could emerge as a major area of cooperation between India and Japan in the light of the threats to the sea-lanes of communication (SLOCs) from both state and non-state actors. The Indian Navy is the only Asian Navy which operates two aircraft carriers. The Indian Coast Guard and Navy have been very proactive in the fight against piracy and in the past had rescued the Japanese-owned vessel, $M V$ Alondra Rainbow from pirates in November 1999 and this made Japan realise the importance and the ability of the Indian Coast Guard. Japan is a net-energy importer and hence the security of its sea-lanes of communication is critically important, especially after the Fukushima earthquake of March 2011 which has crippled the nuclear energy sector in Japan. Tokyo has stationed troops in Djibouti ${ }^{12}$ for anti-piracy operations and the Indian Navy's role is very critical for ensuring that supplies reach this base and also for its security. The Indian Navy has also been regularly organising naval exercises with a host of navies in Southeast Asia, East Asia and Oceania. India has also been actively promoting the Indian Ocean Rim Association (IORA), ostensibly to maintain its primary status in the Indian Ocean region.

In the elections of May 2016, Prime Minister Narendra Modi came to power at the head of a BJP-led NDA government which commands an overwhelming majority in the lower(and more powerful house) of the Indian Parliament, the Lok Sabha. This means it will not be prone to the pulls and pressures of coalition governments unlike the earlier governments and hence the Central government will be able to take tough decisions when it comes to both economic and political matters. Hence, this will also reflect positively in Indo-Japanese relations as well and help them to reach their full potential.

There should also be a time-bound implementation of projects funded by Japan. Given the high premium given on time management and efficiency in Japan, this will help offset the negative image of India in the eyes of some Japanese observers and in turn fetch a lot of goodwill for India.

India will also need to show Japan that it wants close ties with it. Many a times, Japanese observers have lamented that India is unwilling to take a stand against Beijing. India and China are collaborating in international forums like the BRICS and have pooled in along with the other BRICS member countries like Russia, South Africa and Brazil to set up the New Development Bank or the BRICS Bank with an initial corpus of $\$ 100$ billion. $^{13}$

At a time when the term Indo-Pacific is getting increasing currency, thus reflecting the shared interests of nations on the Indian Ocean and the Pacific Ocean seaboard, it is imperative for democratic countries like India and Japan to cooperate to ensure that the whole region remains a level-playing ground for all. In addition, as India's relations with the United States improves, there will be many opportunities for cooperation between India, Japan and the United States. In the future, the kizuna (bond) between Asia's largest democracy and its most prosperous will be further strengthened. Now, with

12 "Japan Opens Military Base in Djibouti to Help Combat Piracy", available at http:/ /www. bloomberg.com/news/articles/2011-07-08/japan-opens-military-base-in-djibouti-to-helpcombat-piracy, accessed on 12 April, 2015.

13 "Brics Nations to Create \$100bn Development Bank", BBC News, available at http:/ /www. bbc.com/news/business-28317555, accessed on 12 April, 2015. 
India's "Look-East Policy" been rechristened as "Act East", it is all the more important that India deepens its engagement with Japan in all fields. On the other hand, as Japan tries to become a normal nation again, its relations with India will be very crucial and one that will be watched with great anticipation across the world. 